\title{
Halloysite nanotubes-polymeric nanocomposites: characteristics, modifications and controlled drug delivery approaches
}

\author{
(Nanocompósitos poliméricos com nanotubos de haloisita: \\ características, modificações e atuação como sistemas \\ de liberação controlada de fármacos)
}

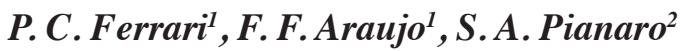 \\ ${ }^{I}$ Department of Pharmaceutical Sciences; ${ }^{2}$ Department of Materials Engineering, \\ State University of Ponta Grossa, Ponta Grossa, PR, Brazil
}

\begin{abstract}
Halloysite nanotubes (HNTs) are aluminosilicate nanoclay mineral which have a hollow tubular structure and occurs naturally. They are biocompatible and viable carrier for inclusion of biologically active molecules due to the empty space inside the tubular structure. In this article, the HNTs main characteristics, and the HNTs-polymeric nanocomposite formation and their potential application as improvement of the mechanical performance of polymers and entrapment of hydrophilic and lipophilic substances are summarized. Recent works covering the increment of HNTs-polymeric nanocomposites and presenting promising employment of these systems as nanosized carrier, being suitable for pharmaceutical and biomedical applications, based on earlier evidence in literature of its nature to sustain the release of loaded drugs, presenting low cytotoxicity, and providing evidence for controlled drug delivery are reviewed.
\end{abstract}

Keywords: nanoclay, bio-nanocomposites, functionalization, sustained drug release, nanotechnology.

\section{Resumo}

Nanotubos de haloisita (NTH) são nanoargilas de silicato de alumínio com estrutura naturalmente tubular. Eles são biocompatíveis e apresentam viabilidade como carreador de moléculas biologicamente ativas devido ao seu espaço interno na estrutura tubular. Neste artigo as principais características dos NTH e a obtenção de nanocompósitos poliméricos com NTH, e suas potenciais aplicações para o aperfeiçoamento das propriedades mecânicas dos polímeros e como carreador de substâncias hidrofílicas e lipofílicas são revisadas. Revisam-se os trabalhos recentes publicados sobre nanocompósitos poliméricos com NTH e apresenta-se o promissor emprego desses sistemas como carreadores, devido à sua capacidade de sustentar a liberação de fármacos em escala nanométrica, adequados para aplicação na área farmacêutica e biomédica, apresentando baixa citotoxicidade e promovendo a liberação controlada de fármacos. Palavras-chave: nanoargila, bionanocompósitos, funcionalização, liberação sustentada de fármacos, nanotecnologia.

\section{INTRODUCTION}

Halloysite nanotubes (HNTs) are a class of natural clays with the same chemical composition as kaolinite and have a tubular morphology, resulting from the wrapping of the clay layers (typically 10 to 15 aluminosilicate layers roll into a cylinder) [1,2]. Natural HNTs have a range of variations and the differences arise from the structure and chemistry of the precursor mineral phase from which is formed and the environmental conditions, leading to crystallization in different forms. Their lengths range from 400 to $1000 \mathrm{~nm}$ (commercially available) or to $5000 \mathrm{~nm}$, found in natural deposits [3]; the inner diameter and the outer diameter of the tubes range from 10 to $40 \mathrm{~nm}$ and 40 to $70 \mathrm{~nm}$, respectively, depending on their provenance and has tubular microstructures that ensure their high aspect ratio (length/ diameter) from 10 to $50[4,5]$. The main difference between HNTs and the other aluminosilicate minerals is their unique nanotubular structure. This structure, good biocompatibility and very low cytotoxicity make them promising to the development of new products, especially polymeric nanocomposites as carriers for drugs [6,7]. Price et al. [8] first suggested the use of the HNTs for drug loading and controlled release followed by others $[1,9,10]$. Drug, proteins or other chemicals may be loaded into the clay tubes at $10-15 \mathrm{wt} \%$, kept for a long time and released in aqueous 
media during 10 to $50 \mathrm{~h}$ controlled by lumen opening and concentration gradient [11].

Polymeric nanocomposites have attracted intense research interest owing to their unique physical and chemical properties resulted from the combination of organic and inorganic materials in single compound. HNTs-polymeric nanocomposites provide also a significant enhancement in mechanical properties (5\% HNTs doping gives 30$50 \%$ tensile strength increase). This enables the design of smart composite materials with synergistically improved strength and adhesivity combined with controlled release of drugs [11]. The different chemical composition of the inner (aluminol) and outer (siloxane) surfaces of HNTs allows for the selective functionalization of the lumen and exterior, to optimize the properties of the nanocomposites making this material suitable for the design of composites for biomedical applications [4]. HNTs outer and innermost are polar compounds that provide good dispersion in polar polymers such as epoxy, polyamides, polyethyleneimine, polyvinyl alcohol, polyacrylates and biopolymers such as polysaccharides pectin, starch and chitosan. HNTs also admix well to medium polarity polymers such as polyvinylchloride and even with low polar polymers, like polyethylene and polypropylene $[2,12,13]$.

Several applications can be studied using HNTs in medical and pharmaceutical areas and the aim of this paper is to discuss recent studies on HNTs-polymeric nanocomposites as carrier for bioactive substances with sustained and controlled drug release. So, a review on HNTs structure, forms to functionalize the nanotubes to optimize the nanocomposite formation, and recent uses of nanocomposites as carrier for controlled drug delivery are presented.

\section{HNTS CHARACTERISTICS}

HNTs structure and properties: HNTs (Fig. 1) are a kind of aluminosilicate clay with hollow nanotubular structure (diameters typically smaller than $100 \mathrm{~nm}$ ) and are mined from natural deposits in countries like China, New Zealand, USA, Brazil and France [14]. It is usually white but is also sometimes slight red and the stone-like raw halloysite is easily ground into powder. Commercial deposits of pure HNTs, i.e. no mixed with kaolinite, are rare [15]. The molecular formula for $\mathrm{HNTs}$ are $\mathrm{Al}_{2} \mathrm{Si}_{2} \mathrm{O}_{5}(\mathrm{OH})_{4} \cdot \mathrm{nH}_{2} \mathrm{O}$. Halloysite's layer silicate and the crystal structure are formed by two building blocks: i) sheets of corner sharing $\left[\mathrm{SiO}_{4}\right]$ tetrahedra; and ii) sheets of edge sharing $\left[\mathrm{AlO}_{6}\right]$ octahedral. The layers building up the final structure are composed by one of each of these sheets, octahedrally coordinated $\mathrm{Al}^{3+}$ and tetrahedrally coordinated $\mathrm{Si}^{4+}$ in a $1: 1$ stoichiometric ratio (dioctahedral layer silicate) [14]. In summary, the external surface is predominantly covered by siloxane ( $\mathrm{Si}-$ $\mathrm{O}-\mathrm{Si}$ ) groups, with some silanol ( $\mathrm{Si}-\mathrm{OH})$ and aluminol (Al$\mathrm{OH})$ groups exposed at the edges of the tube, and the internal surface contains aluminol groups $[16,17]$.

The water molecules are sitting between two consecutive

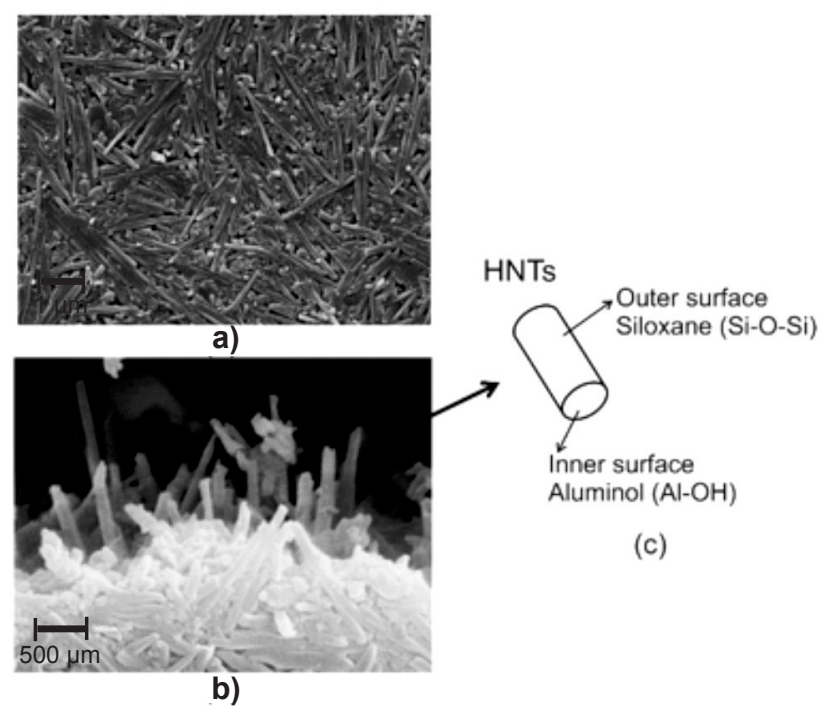

Figure 1: Scanning electron microscopy images of HNTs (halloysite nanotubes) structure $(\mathrm{a}, \mathrm{b})$, and surface scheme showing HNTs chemical composition (c).

[Figura 1: Micrografias obtidas por microscopia eletrônica de varredura da estrutura dos NTHs (nanotubos de haloisita) $(a, b)$ e esquema da superfície mostrando a composição química dos NTHs (c).]

layers (the unit layers of a hollow tubular structure are separated by a monolayer of water molecules) and create slight differences in the relative orientation between neighboring layers might give rise to the differences in the symmetry of the final structure [18]. When $n=2$ (molecular formula), HNTs are in a hydrated state with one layer of water in the interlayer spaces. In this case, the materials are called HNTs- $10 \AA$. When heating the HNTs- $10 \AA$ under mild conditions $\left(30-110^{\circ} \mathrm{C}\right)$, the water between the layers is lost, triggering an irreversible change into HNTs- $7 \AA(n=0)[2$, 19]. HNTs contain two types of hydroxyl groups, inner and outer hydroxyl groups, which are situated between layers and on the surface of the nanotubes, respectively. They can be easily dispersed in water or polar polymers, but are also dispersed in some low polar polymers [20]. The surface of HNTs is mainly composed of O-Si-O groups and siloxane ( $\mathrm{Si}-\mathrm{O}-\mathrm{Si})$ surface $[21]$.

Liu et al. [22] described typical analysis data of HNTs relative as their characteristics according to Table I. The regular tubular morphology, bulk structure, rich mesopores, high aspect ratio, small dimension and high strength suggest that HNTs have a potential uses in high-performance polymeric nanocomposites. The pore size distribution for HNTs is broadly bimodal. The first peak is attributed to internal/surface pores, including spaces between the overlaps of folded HNTs sheets and the second peak is attributed to the central lumen of the tubes. HNTs have relatively few tubetube interactions due to chemical and geometrical aspects and do not tend to agglomerate. Chemically, few hydroxyl groups and siloxane are located on the HNTs surfaces, revealing that the tube-tube interactions are relatively weak. Geometrically, the tube-like morphologies with a proper 
Table I - Main physical and chemical characteristics of halloysite nanotubes (HNTs).

[Tabela I - Principais características físicas e químicas dos nanotubos de haloisita (NTHs).]

\begin{tabular}{|c|c|c|c|}
\hline HNTs characteristic & Value & Comment & Reference \\
\hline Elastic modulus & $230-340 \mathrm{GPa}$ & & [22] \\
\hline Mean particle size & $50-400 \mathrm{~nm}$ & $143 \mathrm{~nm}$ to $5 \mathrm{wt} \%$ aqueous solution & {$[4,5]$} \\
\hline BET surface area & $20.0-100.0 \mathrm{~m}^{2} . \mathrm{g}^{-1}$ & & {$[22]$} \\
\hline Lumen space & $10.7-39 \%$ & & {$[22]$} \\
\hline Inner diameter & $10-40 \mathrm{~nm}$ & & {$[23]$} \\
\hline External diameter & $40-60 \mathrm{~nm}$ & & {$[3]$} \\
\hline Density & $2.14-2.59 \mathrm{~g} . \mathrm{cm}^{-3}$ & $\begin{array}{l}\text { Low, compared to other fillers, such as talc, } \\
\text { calcite } \mathrm{CaCO}_{3} \text {, montmorillonite and kaolinite }\end{array}$ & {$[22]$} \\
\hline Pores space & $14-46.8 \%$ & & {$[24]$} \\
\hline $\begin{array}{l}\text { Cation exchange } \\
\text { capacity }\end{array}$ & $\begin{array}{l}\text { Dehydrated HNTs: } 5-10 \mathrm{meq} / 100 \mathrm{~g} \\
\text { Hydrated HNTs: } 40-50 \mathrm{meq} / 100 \mathrm{~g}\end{array}$ & & {$[25]$} \\
\hline Surface charge & $\begin{array}{c}\text { Negative outer - siloxanes and } \\
\text { silanols/aluminols } \\
\text { Positive inner - aluminols }\end{array}$ & $\begin{array}{l}\text { Predominantly negative over physiologically } \\
\qquad \mathrm{pH} \text { range }(>2)\end{array}$ & {$[21,24]$} \\
\hline
\end{tabular}

aspect ratio generate few opportunities for large-area contact between tubes [22].

According to [24], HNTs have small permanent negative charge (Table I), which is independent of $\mathrm{pH}$. It is suggested that, because the tubular form of halloysite, the Si-tetrahedral sheet occurs on the external surface with the Al-octahedral sheet on the inside. Alumina has positive charge up to $\mathrm{pH}$ 8.5, while silica is negative above $\mathrm{pH} 1.5$ (physiologically relevant $\mathrm{pH}$ range) [21]. The dispersion behavior of HNTs is therefore more strongly influenced by the external $\mathrm{Si}$ tetrahedra, with a very low point of zero charge $(\mathrm{pH}<3.0)$, and continuous dissociation of edge $\mathrm{SiOH}$ groups results in a $\mathrm{pH}$ independent negative charge [26]. The different ionization properties and surface charge can be evident from zeta-potentials of their colloids in water. This allows for the selective loading of negatively charged molecules inside the HNTs lumen $[2,27]$.

\section{HNTS-POLYMERIC NANOCOMPOSITES}

HNTs-polymeric nanocomposites are a class of materials that are composed of both an organic matrix and a dispersed inorganic phase. Compared to conventional composite materials, these hybrid materials can improve the mechanical, thermal and barrier properties of polymers with low filler [28].

HNTs and polymers interactions: based on HNTs characteristics and properties, several studies to obtain nanocomposites by interaction between HNTs and polymers are being developed [2]. Due to the high aspect ratio of HNTs and their nanoscale dimensions, HNTs are excellent reinforcement materials for different polymers. The interfacial interactions between the HNTs and polymers can be tailored using chemical or physical approaches. HNTs can enhance the mechanical properties of the polymers at high temperatures under both dynamic and static conditions and the strength, modulus, stiffness and impact resistance of polymers can be increased simultaneously by HNTs [29]. HNTs have few hydroxyl groups and siloxane located on the HNTs surfaces revealing a relatively weak interaction between two HNTs and consequently, a uniformly dispersed morphology is usually obtained in HNTs and polymer nanocomposites [22]. Once HNTs can be readily dispersed in non-polar polymers using shear due to the interactions between the tubes and the polymer, the natural hydrophobicity of HNTs is not sufficient for interfacial adhesion in composite systems. Further hydrophobic treatment of HNTs should be performed before adding them into polymers to maximize their interfacial interactions. For example, the hydrophobic lumen can encapsulate neutral and hydrophobic guest molecules by partitioning with a polar solvent, while the solid polar shell stabilizes the dispersion of the nanotube in water and retains the guest molecules [22, 30]. The surface charge of HNTs, predominantly negative, facilitates electrostatic attractions with cationic polymers. These interactions can be used when designing the interface of polymer nanocomposites [22, 31]. The positive (below $\mathrm{pH} 8.5$ ) charge of the inner lumen promotes loading of HNTs with negative macromolecules within void spaces, which are at the same time repelled from the negatively charged outer surfaces [21]. Additionally, inorganic nanoparticles typically do not interact well with organic polymers, resulting in poor dispersion and adhesion. Thereby, the organic modification of nanoparticles can promote both higher compatibility between organic and inorganic phases and improved interfacial interactions between a polymer and filler [28, 32].

HNTS modifications and functionalizations: in order to optimize the properties of the HNTs-polymeric 
Table II - Examples of purification, modification and functionalization process of halloysite nanotubes (HNTs). [Tabela II - Exemplos de processos de purificação, modificação e funcionalização dos nanotubos de haloisita (NTHs).]

\begin{tabular}{|c|c|c|c|}
\hline Modification & Application & Method and substances applied & Reference \\
\hline \multirow[t]{2}{*}{ HNTs purification } & Dispersion-centrifugation-drying technique & $\begin{array}{l}10 \mathrm{wt} \% \text { water suspension with heating to } \\
\qquad 60^{\circ} \mathrm{C}\end{array}$ & {$[5,38]$} \\
\hline & $\mathrm{H}_{2} \mathrm{O}_{2}$ to remove organic impurities & $\mathrm{H}_{2} \mathrm{O}_{2}$ aqueous solution $(30 \%)$ & [39] \\
\hline \multirow{6}{*}{$\begin{array}{l}\text { Covalent } \\
\text { functionalization }\end{array}$} & $\begin{array}{c}\text { Reduction of the polarity; shielding of the hydroxyl } \\
\text { groups; inclusion of hydrocarbons; creation of } \\
\text { functional groups }\end{array}$ & $\begin{array}{l}\text { Grafting silanes via condensation } \\
\text { between the hydrolyzed silanes and the } \\
\text { surface hydroxyl groups of the HNTs }\end{array}$ & {$[40]$} \\
\hline & Increase the interfacial adhesion of the HNTs & $\begin{array}{l}\text { Y-glycidoxypropyltrimethoxysilane; } \\
\text { 3-(trimethoxysilyl)propyl methacrylate }\end{array}$ & {$[7,22]$} \\
\hline & $\begin{array}{l}\text { Surface modifier (introduce double bonds onto the } \\
\text { surface of HNTs to form sites for polymerization) }\end{array}$ & $\begin{array}{l}\text { 3-methacryloxypropyltrimethoxysilane; } \\
\text { poly(2-hydroxyethyl methacrylate); } \\
\text { poly(2-hydroxyl ethyl methacrylate-b- } \\
\text { methyl methacrylate) }\end{array}$ & {$[41]$} \\
\hline & Enhance biocompatibility of several nanomaterials & 3-Aminopropyltriethoxysilane & {$[4,35]$} \\
\hline & $\begin{array}{l}\text { Improve dispersion in polymers (intercalation and } \\
\text { interaction of lumen space inside HNTs) }\end{array}$ & $\gamma$-methacryloxypropyl trimethoxysilane & {$[5]$} \\
\hline & $\begin{array}{l}\text { Enhance the negative charge or become neutral HNTs } \\
\text { surface }\end{array}$ & $\begin{array}{l}\text { Cationic and anionic surfactants: } \\
\text { sodium dodecanoate and decyl trimethyl } \\
\text { ammonium bromide }\end{array}$ & {$[33]$} \\
\hline Covalently & $\begin{array}{l}\text { Change morphology of nanotubes to nanoplatelets: } \\
\text { increase the basal spacing from } 7.2 \text { to } 15.1 \AA\end{array}$ & Phenyl phosphonic acid & {$[42,43]$} \\
\hline $\begin{array}{l}\text { grafting } \\
\text { phosphonic acid }\end{array}$ & Remove the air from nanotubes lumen - drug loading & $\begin{array}{l}\text { Octadecyl phosphonic acid: bond to the } \\
\text { alumina sites at the tube lumen but not } \\
\text { the outer siloxane surface }\end{array}$ & {$[31]$} \\
\hline \multicolumn{4}{|c|}{ Non-covalent functionalization } \\
\hline Alkali treatment & $\begin{array}{l}\text { Low concentration } \mathrm{NaOH} \text { : to maximize the density of } \\
\text { hydroxyl groups on silica; increase the dispersibility of } \\
\text { HNTs in polar solvents }\end{array}$ & $\begin{array}{l}\mathrm{NaOH} \text { react with the tetrahedral silicate } \\
\text { to create silanol }(\mathrm{Si}-\mathrm{OH}) \text { groups }\end{array}$ & {$[39,44]$} \\
\hline Acid activation & $\begin{array}{c}\text { Disaggregation of HNTs: elimination of mineral } \\
\text { impurities and inner layers dissolution; replacement } \\
\text { of interlayer cations by protons; better exposure of the } \\
\text { external adsorption sites }\end{array}$ & $\mathrm{H}_{2} \mathrm{SO}_{4}$ & {$[45,46]$} \\
\hline $\begin{array}{l}\text { Acid and heat } \\
\text { activation }\end{array}$ & $\begin{array}{c}\text { Dehydroxylation of the structural aluminol groups: } \\
\text { decrease of the adsorption capacity for cationic drug; } \\
\text { HNTs becomes amorphous }\end{array}$ & $\begin{array}{l}\text { Structural rearrangement: changes in the } \\
\text { pore structure and surface properties; } \\
\text { remove the physically bounded water }\end{array}$ & {$[18]$} \\
\hline
\end{tabular}

nanocomposites, the interface between the nanotube and the polymer must be engineered. Therefore, functionalizing HNTs is extremely important for processing and enhancing the properties of HNTs and polymer nanocomposites, to improve mechanical and thermal properties, because the functionalization improves the dispersion and stressstrain transfer [22]. Several studies reported that the functionalization enhances the biocompatibility of several nanomaterials [16, 28, 33-35], enhancing the chemical affinity of HNT with the polymer through hydrogen bonding between the amine groups and the polymer carboxylic moieties [4]. In recent years, the functionalization of HNTs has attracted considerable interests in order to improve their properties and performance of the related products and to adsorb drugs (forming complexes) by various methods [18, 29, 31, 36]. Different outside/inside chemistry of HNTs $\left(\mathrm{SiO}_{2} / \mathrm{Al}_{2} \mathrm{O}_{3}\right)$ allows for selective chemical modification of HNTs surfaces, adjusting their surface for dispersing in polymers of different polarities and loading HNTs both with hydrophilic or hydrophobic chemical agents [1,30,37]. Table II summarizes several mechanisms to HNTs modifications and functionalization, including main applications and substances applied.

Covalent functionalization (Fig. 2a): can improve the dispersion of the HNTs in solvents and polymers by increasing their interfacial compatibility, optimizing the nanocomposite properties [17, 22]. Functionalization of the HNTs with organosilanes increases their degree of dispersion within the polymer matrix, therefore improving the mechanical properties of nanocomposites (tensile strength and tensile modulus), while decreased their thermal resistance [16, 47, 48].

Non-covalent functionalization: the acidic and alkaline treatment methods (Fig. 2b) provided a convenient tool for 


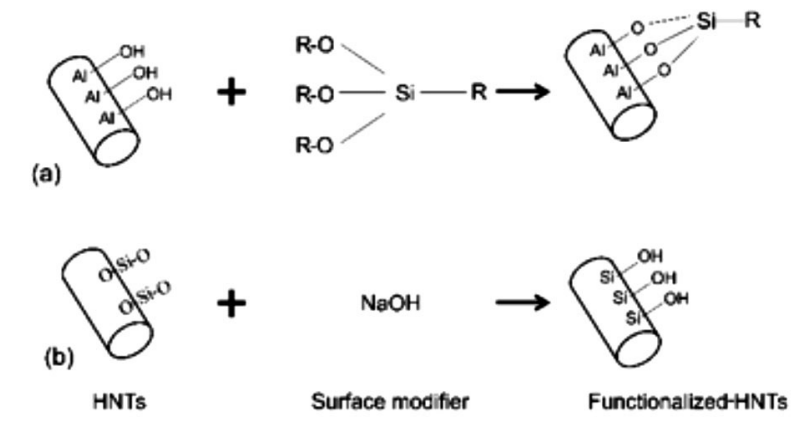

Figure 2: Scheme of HNTs functionalization: (a) example of covalent modification by grafting organosilanes; (b) example of non-covalent modification by alkali treatment.

[Figura 2: Esquema da funcionalização dos NTHs: (a) exemplo de modificação covalente por enxerto de grupos organossilanos; (b) exemplo de modificação não covalente por tratamento alcalino.]

increasing the specific surface area and pore volume of the HNTs without significantly altering of their shape. During the preparation of HNTs-polymeric nanocomposites, the interfacial adhesion between the HNT phase and polymer is not ideal due to the low concentration of polar functional groups on the external surface of HNTs, since the density of hydroxyl groups on the external surface of HNTs is much lower than that of alumina lumen. Thus, the surface functionalized by alkali treatment with sodium hydroxide, creating a high density of hydroxyl groups on the external surface of HNTs leading to a much higher level of dispersion of HNTs in water and organic polar solvents [39].

Many applications for HNTs are constrained by the size of the lumen. Due to the different internal/external chemistry, the selective etching of alumina from the inside of the tube was realized in a reaction with sulfuric acid, preserving the external HNTs diameter. According to [45] the lumen diameter changed from 15 to $25 \mathrm{~nm}$, increasing the tube lumen capacity by 2 or 3 times for the loading and sustained release of active chemical agents. Joo et al. [23] found that the porosity could be tailored by changing the $\mathrm{pH}$ of a water suspension containing HNTs and the characteristics of pores could be applicable for drug delivery systems. HNTs can act as doors for one another, blocking the inner-pore through aggregation or opening it through dispersion. The innerpores of HNTs were open after basic treatment through negative charge dispersion; they were closed after acidic and neutral treatments.

\section{HNTS AS CARRIER OF DRUGS}

An empty lumen of the HNTs is an excellent miniature container for encasing chemical agents [1]. Drugs, proteins or other chemicals may be loaded into the clay tube at 10-25 wt $\%$, released in aqueous media during 10 to $20 \mathrm{~h}$ controlled by lumen opening diameter, diffusion coefficient and concentration gradient. Typically, 6-10 wt\% loading was reached for untreated HNTs and with acid etched lumens HNTs loading reached 20-30 wt\% [8, 45]. Liu et al. [22] show the drug released from the HNTs can last until 100 times longer than the drug alone or in other carriers and adding a polymer coating to the drug-loaded HNT surface further slows the drug release rate. Due to the perfect tubular microstructures, many chemically and biologically active substances can be loaded into the lumen under vacuum or through immersion in saturated drug solution. HNTs also entrap molecules in different ways including adsorption to the external and internal walls of the tubes [49], intercalation [50], and loading into lumen accompanied by condensation/ crystallization of the loaded materials [2, 12, 51, 52]. The lumen size of HNTs is greater than $10 \mathrm{~nm}$, which is sufficiently large to accommodate various guests and the porous materials reduce the diffusional resistance, which is important to adsorption of large molecules [15].

HNTs-biopolymer nanocomposites: bio-nanocomposites represent the new generation of nanocomposites and comprise the nanostructured hybrid materials by combination of biopolymers and an inorganic material with enhanced thermal, mechanical and functional properties [53, 54]. Based on these observations several studies developed a biodegradable polysaccharide as starch and chitosan-based nanocomposite films using HNTs to enhance their functional properties. Sadegh-Hassani and Nafchi [54] introduced HNTs to potato starch matrix to fabricate bio-nanocomposites and concluded that the HNTs improved mechanical properties of the films made from potato starches; permeability to water vapor and oxygen, water absorption capacity and water solubility of the films significantly decreased. Chitosan is a natural polycationic biopolymer that can be dissolved in diluted aqueous acetic acid solution. Due to the protonation of the amines at low $\mathrm{pH}$ (less than 6), the chitosan is positively charged in the solution [50]. Therefore, mixing chitosan with HNTs in acid aqueous solution could result in the electrostatic attraction between them. On the other hand, the amine groups and hydroxyl groups on the chitosan can interact with the Si-O bonds of HNTs via hydrogen bonding interactions, forming a HNTs-chitosan hybrid in solution [55]. Apart from being used to prepare HNTs-cation polymer (as chitosan) bionanocomposites, these interactions can also be employed for the surface-treatment of HNTs. Coating HNTs with cationic polymers that bind onto the negative charges present on the tubule surface (charge neutralization) can slow down drug release.

Chitosan has low mechanical strength, thermal stability and water and gas barrier properties, which has restricted the opportunity for wider applicability. Very recently, mechanical properties of HNTs incorporated chitosan films have been investigated and it has been observed that adding $7.5 \%(\mathrm{w} / \mathrm{w})$ of HNTs increased the tensile stress and Young's modulus of nanocomposite by $134 \%$ and $65 \%$, respectively $[55,56]$. De Silva et al. [57] report on a feasibility study to establish a simple solution casting approach for fabricating chitosan membranes reinforced by HNTs; they found that membranes with $5 \%(\mathrm{w} / \mathrm{w})$ of HNTs had Young's modulus and tensile strength improved 


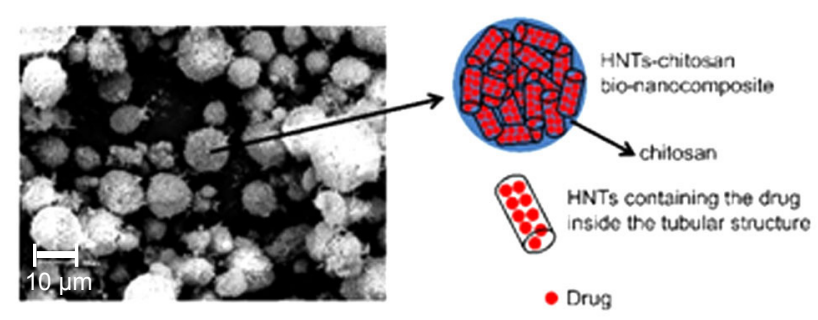

Figure 3: Scanning electron microscopy image of HNTs-chitosan bio-nanocomposites obtained by spray drying technique and schematic representing load of drug inside the HNTs.

[Figura 3: Micrografia obtida por microscopia eletrônica de varredura de bionanocompósitos de quitosana-NTHs obtidos pela técnica de spray drying e representação esquemática do fármaco carreado dentro do NTH.]

by $21 \%$ and $34 \%$, respectively, due to uniform dispersion of HNTs and interactions between chitosan's hydroxyl and CO groups with external surface siloxane groups of the HNTs. Wang et al. [58] prepared magnetic microspheres consisting of 2-hydroxypropyltrimethyl ammonium chloride chitosan and HNTs for the controlled release of ofloxacin by in situ crosslinking with glutaraldehyde in the spray drying process. They observed that the amino groups of modified chitosan could react with aldehyde groups of glutaraldehyde forming polymeric network and the introduction of HNTs improved the bioavailability of the drug in the gastroretentive drug delivery system. Microparticles constituted by HNTs and chitosan also were prepared by spray drying technique to controlled drug delivery (not published results) and Fig. 3 shows the micrograph obtained by scanning electron microscopy. Microparticles are spherical and their surface showed irregular characteristic due to the HNTs presence in large amount, showing the nanotubular structure of the bionanocomposites.

Modified HNTs to controlled drug release: intending to investigate load and release behaviors of various pharmaceuticals and others agents, Yuan et al. [59] evaluated the release of a dye molecule from modified and unmodified HNTs with $\gamma$-aminopropyltriethoxysilane. They observed an initial burst followed by a prolonged release which was attributed to the release of dye loaded inside the channels of HNTs. Surface modification clearly extends the time over which release occurred, from under $5 \mathrm{~h}$ to over $30 \mathrm{~h}$, greatly enhancing the controlled release properties. This is due to the strengthened electrostatic interaction between the dye and the $\mathrm{NH}_{3}{ }^{+}$covered lumen surface. In contrast, the initial burst of dye from unmodified HNTs was $\mathrm{pH}$ dependent. This suggests that the exposed silanol or aluminol groups at the edge sites of the outer surface were grafted, capturing the dye molecules by electrostatic attraction, which was more stable than the weak binding of the dye on the unmodified HNTs, because more acidic conditions promote the formation of $\mathrm{NH}_{3}{ }^{+}$and thus strengthen the electrostatic attraction, leading to less initial release of dye from the amine-modified surface of HNTs. 3-aminopropyltriethoxysilane-modified
HNTs were used as ibuprofen carrier for controlled release [60]. The drug was mainly encapsulated into the lumen and partially loaded onto the external surface of the HNTs and the covalent modification increased the loading of drug by creating an electrostatic attraction between the introduced aminopropyl groups of the grafted and the carboxyl groups of ibuprofen. The strong affinity (electrostatic attraction) in modified HNTs slowed down the release of drug and changed the release mechanism from Fickian diffusion in the unmodified HNTs to non-Fickian diffusion in the modified HNTs. Kirimlioglu et al. [61] developed a braintargeted HNTs-GABA loaded to treat epilepsy. In vitro and in vivo studies showed drug sustained release and low cytotoxicity and provided evidence for brain delivery and seizure inhibition of GABA in epilepsy model on rats. HNTs containing GABA provided retardation in latency time, decrease in ending time of convulsion, duration of severe convulsion and mortality ratio.

Anticancer drug-loaded HNTs studies: drug loaded HNTs have been used to inhibit cell proliferation and to induce apoptosis, thus showing its potential as a tool to delivery chemotherapeutic drug loads to tumor sites [4, 62-66]. In this way, a focal and sustained drug release can be delivered to the targeted tumor sites and therefore, prevent potential postoperative surgical tumor recurrence and metastasis. Positively charged HNTs functionalized with triazolium salts (f-HNTs) were employed as a carrier for curcumin molecules delivery in [63] and for cardanol in [64]. A cationic surface was desirable as it promotes the interaction between the nanoparticles and the cells and hence increases the rate and extent of internalization. The functionalization served for two purposes: introducing a positive charge on the HNTs carrier and verifying whether the presence of the biological active triazolium moiety could exert a synergic effect with curcumin and cardanol. The interaction between HNTs with curcumin was evaluated by dynamic light scattering measurements and UV-Vis spectroscopy and they hypothesized the coexistence of two different "curcumin species", one encapsulated and the other adsorbed onto external surface of f-HNTs. The introduction of a positive charge onto the external surface of f-HNTs makes the curcumin being preferentially adsorbed onto the external surface and the interaction of curcumin and f-HNTs was responsible for the difference in drug release behavior. Release of curcumin from HNTs can be considered the phase of desorption of the previously adsorbed drug molecules from an external HNTs surface [67, 68]. So, it was concluded that the triazole moiety, into the HNT surface, had a synergic effect with curcumin, which make f-HNT an ideal carrier for anti-cancer therapies as confirmed by cytotoxic assays, performed on a large panel of cancer cell lines, showing that the complex f-HNT/curcumin is active in several tumor models [63]. Concerning the study with cardanol, the drug release was influenced by the $\mathrm{pH}$ and was prolonged. Cytotoxicity experiments on several cell lines proved that cardanol is a promising anticancer and that the use of chemically modified nanotubes exercises synergic 
effects likely improving the permeability of cells to cardanol [64].

A work used HNTs to encapsulate resveratrol and evaluate their release profile and the drug efficacy on MCF-7 (breast cancer cell line), as apoptotic agent [4]. Resveratrol-HNTs showed slow $48 \mathrm{~h}$ of release with constant release rate. An additional functionalization for controlling the release rate was made using layer-by-layer polyelectrolyte multilayer coating (using protamine salt and dextran sulfate sodium salt) onto the tube external surface and further decrease of release rate was demonstrated. Layer-by-layer is a common technique to hold the drug layer between scheduled layers of polymers. Then, the release of targeted molecules would be more controlled by the degradation of the biocompatible polymers. Resveratrol-HNTs coated with protamine and dextran sulfate sodium salts had an apoptotic effect because these two polyelectrolytes were spontaneously degraded under physiological conditions and the resveratrol inside HNTs has been slowly released and it kills the MCF-7 cells [4]. Sun and Mills [65] evaluated cellular growth on osteosarcoma cells (UMR-106) treated by HNTs-(different anti-cancer) drugs loaded. Pure HNTs group stayed the same as the control, while the cell densities in all the other groups were decreased significantly. In the HNTs/methotrexate group, a few dying cells were observed, but proliferation was significantly inhibited. In the HNTs/artermisinin and HNTs/ taurolidine groups, apoptosis was observed and proliferation was also arrested when compared to the control as shown after testing with an apoptosis immunehistochemical kit. Apoptosis was also observed in the HNTs/quercetin group as evidenced by the bright apoptotic bodies.

HNTs loaded with a triazole dye brilliant green drug, capable for suppressing mitochondria in the malignant cells, coated with dextrin to clog the tube opening until the cell absorption were developed [69]. The accumulation and enzymatically induced release of drug occurred exclusively in cells prone to internalization of the HNTs with higher proliferation rates, which is a characteristic of malignant cells. Non-malignant cells do not suffer from the introduction of NHTs with anticancer drug; as a result, drugloaded dextrin-HNTs is accumulated selectively in tumor cells. Doxorubicin (DOX) is one of the well-established and effective anticancer drugs against various types of cancers. Lee et al. [62] developed DNA-wrapped HNTs being a platform for loading DOX; they suggested two mechanisms to load DOX to DNA-wrapped HNTs: first, DOX intercalates with DNA and secondly, DOX, which is a cationic drug, is adsorbed onto the surface of the tubules by electrostatic attraction. The cytotoxicity of free DOX and the complex was evaluated against adenocarcinomic human alveolar basal epithelial A549 cells. Results demonstrated slow DOX release from complex, probably during the initial phase, which would contribute to minimize toxic effects of DOX on normal tissues after administration and DOX-loaded DNA wrapped HNTs can be ideal sustained drug delivery systems. Wu et al. [66] prepared a gene delivery system of HNTs-based multifunctional nanocarrier for loading, intracellular delivering and cellular tracking of siRNA. The developed functionalization-HNTs carriers exhibited efficient intracellular transporting and high delivery efficiency of siRNA. The system could effectively induce the knockdown of the target surviving gene in PANC-1 cells (human pancreatic carcinoma, epithelial-like cell line) and improve the antitumor activity of siRNA.

The elucidation of the toxicity of HNTs toward living organisms is crucially important [3]. Halloysite has a good biocompatibility, which means that tissue contact with halloysite is not harmful, because it was assessed for both cell cultures [70, 71] and invertebrate model [72]. The uptake and toxic effects of halloysite have been investigated using human cell lines (breast cancer cells and epithelial adenocarcinoma cells), suggesting that the viability of the human cells was preserved at relatively low concentrations [71]. However, HNTs are not biodegradable, i.e. there are no biological mechanisms to degrade these alumosilicate clays in the body [3]. Some authors describe that due to their small size the HNTs will be naturally removed from the body [73]. The degradable behavior in vivo, biodistribution, and excretion from the body of drug loaded-HNTs are under investigation by several researchers $[3,71,73]$.

\section{CONCLUSIONS}

HNTs-polymeric nanocomposites, modified/ functionalizationed-HNTs and HNTs as drug carrier exhibit reduced gas permeability, enhanced mechanical properties, improved thermal stability, control of drug delivery and target to specific cells and organs when compared to pristine HNTs, pure polymers and free drug. The final performance of these materials is directly related to several parameters such as polymer-HNTs interactions, type of modification and used substance, and the dispersion inside the polymer matrix and the drug incorporation as well as the preparation method. The safety profile against model cell lines for in vivo toxicity study of HNTs make an important case for commercial pharmaceutical and biomedical applications based on earlier evidence in literature of its nature to sustain the release of loaded drugs.

\section{ACKNOWLEDGMENTS}

The authors thank Complex Multi-User Laboratories (CLABMU) of State University of Ponta Grossa for SEM micrographs.

\section{REFERENCES}

[1] Y.M. Lvov, A. Aerov, R. Fakhrullin, Adv. Colloid Interface Sci. 207 (2014) 189.

[2] Y.M. Lvov, E. Abdullayev, Prog. Polym. Sci. 38 (2013) 1690.

[3] Y.M. Lvov, W. Wang, L. Zhang, R. Fakhrullin, Adv. Mater. 28 (2016) 1227.

[4] S. Del Buffa, M. Bonini, F. Ridi, M. Severi, P. Losi, 
S. Volpi, T.A. Kayal, G. Soldani, P. Baglioni, J. Colloid Interface Sci. 448 (2015) 501.

[5] P. Pasbakhsh, G.J. Churchman, J.L. Keeling, Appl. Clay Sci. 74 (2013) 47.

[6] V. Vergaro, Y.M. Lvov, S. Leporatti, Macromol. Biosci. 12 (2012) 1265.

[7] S. Zhong, C. Zhou, X. Zhang, H. Zhou, H. Li, X. Zhu, Y. Wang, J. Hazard Mater. 276 (2014) 58.

[8] R. Price, B. Gaber, Y. Lvov, J. Microencap. 18 (2001) 713.

[9] J. Forsgren, E. Jämstorp, S. Bredenberg, H. Engqvist, M. Strømm, J. Pharm. Sci. 99 (2010) 219.

[10] C.J.Ward, S. Song, E.W.Davis, J. Nanosci. Nanotechnol. 10 (2010) 6641.

[11] T.G. Shutava, R.F. Fakhrullin, Y.M. Lvov, Curr. Opin. Pharmacol. 18 (2014) 141.

[12] Y.Lvov, R. Price, in Bio-inorganic hybrid nanomaterials, Eds. E. Ruiz-Hitzky, K. Ariga, Y. Lvov, Wiley, London (2008) 440.

[13] Y. Zheng, A. Wang, J. Macromol. Sci. Pure 47 (2010) 33.

[14] D. Rawtani, Y.K. Agrawal, Rev. Adv. Mater. Sci. 30 (2012) 282.

[15] A.C.V. Coelho, P.S. Santos, Quim. Nova 30 (2007) 146. [16] P. Pasbakhsh, H. Ismail, M.N.A. Fauzi, A.A. Bakar, Appl. Clay Sci. 48 (2010) 405.

[17] P. Yuan, P.D. Southon, Z. Liu, M.E.R. Greesn, J.M. Hook, S.J. Antill, C.J. Kepert, J. Phys. Chem. C 112 (2008) 15742 .

[18] Q. Wang, J. Zhang, Y. Zheng, A. Wang, Colloids Surf. B 113 (2014) 51.

[19] F. Bergaya, B.K.G. Theng, G. Lagaly, Handbook of clay science, Elsevier Sci.Technol., Amsterdam (2006).

[20] Y. Fu, D. Zhao, P. Yao, W. Wang, L. Zhang, Y. Lvov, ACS Appl. Mater. Interf. 7 (2015) 8156.

[21] R. Kamble, M. Ghag, S. Gaikawad, B.K. Panda, J. Adv. Sci. Res. 3 (2012) 25.

[22] M. Liu, Z. Jia, D. Jia, C. Zhou, Prog. Polym. Sci. 39 (2014) 1498.

[23] Y. Joo, J.H. Sim, Y. Jeon, S.U. Lee, D. Sohn, Chem. Commun. 49 (2013) 4519.

[24] G. Tari, I. Bobos, C.S.F. Gomes, J.M.F. Ferreira, J. Colloid Interface Sci. 210 (1999) 360.

[25] R.E. Grim, Clay mineralogy, McGraw-Hill, New York (1953).

[26] M.J. Wilson, Rock-forming minerals: sheet silicates: clay minerals, $2^{\text {nd }}$ Ed., Vol. 3C, Geol. Soc., London (2012).

[27] N. Veerabadran, R. Price, Y.M. Lvov, Nano 2 (2007) 215.

[28] T.S. Daitx, L.N. Carli, J.S. Crespo, R.S. Mauler, Appl. Clay Sci. 115 (2015) 157.

[29] K.P. Nicolini, C.R.B. Fukamachi, F. Wypych, A.S. Mangrich, J. Colloid Interface Sci. 338 (2009) 474.

[30] M. Du, B. Guo, D. Jia, Polym. Int. 59 (2010) 574.

[31] W.O. Yah, A. Takahara, Y.M. Lvov, J. Am. Chem. Soc. 134 (2012) 1853.

[32] S. Pavlidou, C.D. Papaspyrides, Prog. Polym. Sci. 33
(2008) 1119.

[33] M.J. Mitchell, C.A. Castellanos, M.R. King, Biomaterials 56 (2015) 179.

[34] Y. Joo, Y. Jeon, S.U. Lee, J.H. Sim, J. Ryu, S. Lee, D. Sohn, J. Phys. Chem. C 116 (2012) 18230.

[35] T.Y. Cheang, B. Tang, A.E. Xu, G.Q. Chang, Z.J. Hu, W.L. He, Z.H. Xing, J.B. Xu, M. Wang, S.M. Wang, Int. J. Nanomed. 7 (2012) 1061.

[36] R.D. White, D.V. Bavykin, F.C. Walsh, Nanotechnology 23 (2012) 65705.

[37] E. Abdullayev, Y. Lvov, J. Mater. Chem. B 1 (2013) 2894.

[38] M.L. Jackson, Soil chemistry analysis: advanced course, Madison, Wisconsin (1956).

[39] S.Zeng, C. Reyes, J. Liu, P.A. Rodgers, S.H. Wentworth, L. Sun, Appl. Polym. 55 (2014) 6519.

[40] M. Poikelispää, A. Das, W. Dierkes, J. Vuorinen, J. App. Polym. Sci. 127 (2013) 4688.

[41] C. Zhou, H. Li, H. Zhou, H. Wang, P. Yang, S. Zhong, J. Sep. Sci. 38 (2015) 1365.

[42] J.L. Guimarães, P. Peralta-Zamora, F. Wypych, J. Colloid Interface Sci. 206 (1998) 281.

[43] Y. Tang, S. Deng, L. Ye, C. Yang, Q. Yuan, J. Zhang, C. Zhao, Compos. Part A 42 (2011) 345.

[44] Q. Wang, J. Zhang, A. Wang, App. Surf. Sci. 287 (2013) 54.

[45] E. Abdullayev, A. Joshi, W.B. Wei, Y.F. Zhao, Y.M. Lvov, ACS Nano 6 (2012) 7216.

[46] D. Banaś, A. Kubala-Kukuś, J. Braziewicz, U. Majewska, M. Pajek, J. Wudarczyk-Moćko, K. Czech, M. Garnuszek, P. Słomkiewicz, B. Szczepanik, Radiat. Phys. Chem. 93 (2013) 129.

[47] D.S. Bag, R. Dubey, N. Zhang, J. Xie, V.K. Varadan, D. Lal, G.N. Mathur, Smart Mater. Struct. 13 (2004) 1263.

[48] H. Chen, H. Muthuraman, P. Stokes, J. Zou, X. Liu, J. Wang, Q. Huo, S.I. Khondaker, L. Zhai, Nanotechnology 18 (2007) 415606.

[49] M. Zhao, P. Liu, Micropororous Mesoporous Mater. 112 (2008) 419.

[50] E. Joussein, S. Petit, J. Churchman, B. Theng, D. Righi, B. Delvaux, Clay Miner. 40 (2005) 383.

[51] E. Abdullayev, Y. Lvov, J. Mater. Chem. 20 (2010) 6681.

[52] E. Abdullayev, Y. Lvov, J. Nanosci. Nanotechnol. 11 (2011) 10007.

[53] M. Darder, P. Aranda, E. Ruiz-Hitzky, Adv. Mater. 19 (2007) 1309.

[54] F. Sadegh-Hassani, A.M. Nafchi, Int. J. Biol. Macromol. 67 (2014) 458.

[55] M. Liu, Y. Zhang, C. Wu, S. Xiong, C. Zhou, Int. J. Biol. Macromol. 51 (2012) 566.

[56] R. Jayakumar, M. Prabaharan, P.T.S. Kumar, S.V. Nair, H. Tamura, Biotechnol. Adv. 29 (2011) 322.

[57] R.T. De Silva, P. Pasbakhsh, K.L. Goh, S. Chai, H. Ismail, Polym. Test. 32 (2013) 265.

[58] Q. Wang, J. Zhang, B. Mu, L. Fan, A. Wang, Carbohydr. Polym. 102 (2014) 877. 
[59] P. Yuan, P.D. Southon, Z. Liu, C.J. Kepert, Nanotechnology 23 (2012) 375705.

[60] D. Tan, P. Yuan, F. Annabi-Bergaya, D. Liua, L. Wang, H. Liu, H. He, Appl. Clay Sci. 96 (2014) 50.

[61] G.Y. Kirimlioglu, Y. Yazan, K. Erol, Ç.Ç. Ünel, Int. J. Pharm. 495 (2015) 816.

[62] Y. Lee, G.E. Jung, S.J. Cho, K.E. Geckeler, H. Fuchs, Nanoscale 5 (2013) 8577.

[63] S. Riela, M. Massaro, C.G. Colletti, A. Bommarito, C. Giordano, S. Milioto, R. Noto, P. Poma, G. Lazzara, Int. J. Pharm. 475 (2014) 613.

[64] M. Massaro, C.G. Colletti, R. Noto, S. Riela, P. Poma, S. Guernelli, F. Parisi, S. Milioto, G. Lazzara, Int. J. Pharm. 478 (2015) 476.

[65] L. Sun, D.K. Mills, Conf. Proc. IEEE Eng. Med. Biol. Soc. (2014) 2920.

[66] H. Wu, Y. Shi, C. Huang, Y. Zhang, J. Wu, H. Shen, N.
Jia, J. Biomater. Appl. 28 (2014) 1180.

[67] S. Dash, P.N. Murthy, L. Nath, P. Chowdury, Acta Pol. Pharm. Drug. Res. 67 (2010) 217.

[68] R.W. Korsmeyer, R. Gurny, E. Doelker, P. Buri, N.A. Peppas, Int. J. Pharm. 15 (1983) 25.

[69] M.R. Dzamukova, E.A. Naumenko, Y.M. Lvov, R.F. Fakhrullin, Sci. Rep. 5 (2015) 10560.

[70] F.R. Ahmed, M.H. Shoaib, M. Azhar, S.H. Um, R.I. Yousuf, S. Hashmi, A. Dar, Colloids Surf. B 135 (2015) 50. [71] V. Vergaro, E. Abdullayev, Y.M. Lvov, A. Zeitoun, R. Cingolani, R. Rinaldi, S. Leporatti, Biomacromol. 11 (2010) 820.

[72] G.I. Fakhrullina, F.S. Akhatova, Y.M. Lvov, R.F. Fakhrullin, Environ. Sci. Nano 2 (2015) 54.

[73] J. Yang, Y. Wu, Y. Shen, C. Zhou, Y. Li, R. He, M. Liu, ACS Appl. Mater. Inter. 8 (2016) 26578.

(Rec. 29/09/2016, Rev. 11/12/2016, Ac. 30/01/2017) 